\title{
The Identification of Multidrug Resistant Microorganisms Including Bergyella Zoohelcum Acquired from the Skin/Prosthetic Interface of Amputees and Their Susceptibility to Medihoney ${ }^{\mathrm{Tm}}$ and Garlic Extract (Allicin)
}

Ruby Harsent

Cardiff Metropolitan University

\section{Paul Smith}

Cardiff Metropolitan University

James Arthur Blaxland ( $\sim$ JABlaxland@cardiffmet.ac.uk)

Cardiff Metropolitan University

Neil Rushmere

Cardiff Metropolitan University

\section{Research Article}

Keywords: Drug-Resistance, Prosthetic, antimicrobials, Medihoney, Allicin, Bergyella, Manuka,

Posted Date: November 9th, 2021

DOI: https://doi.org/10.21203/rs.3.rs-1026595/v1

License: (c) (i) This work is licensed under a Creative Commons Attribution 4.0 International License. Read Full License 


\section{Abstract}

\section{Background}

Users of prosthetic devices face the accumulation of potentially drug-resistant pathogenic bacteria on the skin/prosthesis interface. In this study, we took surface swabs of the skin/prosthesis interface of eleven disabled athletes to identify microorganisms present. In addition to determining their antimicrobial resistance profile, we assessed their sensitivity to Manuka honey and Garlic extract (allicin)

\section{Methods}

Eleven volunteers were directed to swab the skin at the skin/prosthesis interface. After initial isolation of microorganisms we employed the following general microbiological methods; Gram stain, Catalase test, Oxidase test, lactose fermenting capability, haemolytic capability, Staphaurex, mannitol fermenting capability, Streptex; API Staph, 20E, Candida, and BBL crystal identification system tests. Once identified, isolates were analysed for their sensitivity to penicillin, erythromycin. ampicillin, vancomycin, ceftazidime, ciprofloxacin, gentamicin and colistin-sulphate. Isolates were also analysed for their sensitivity to allicin (Garlic Extract (GE)) and Manuka honey (Medihoney ${ }^{\mathrm{TM}}$ ) (MH).

\section{Results}

Eleven isolates were identified, Bacillus cereus, Staphylococcus haemolyticus, Staphylococcus aureus, Micrococcus luteus, Pseudomonas oryzihabitans, Micrococcus spp., Bacillus subtilis, Group D Streptococcus, Pantoea spp., Enterobacter cloacae and Bergyella zoohelcum. All Gram-positive organisms were resistant to 1.5 units of penicillin and $10 \mu \mathrm{g}$ of ampicillin, and two Gram-negatives Pseudomonas oryzihabitans and Bergyella zoohelcum were resistant to $10 \mu \mathrm{g}$ ceftazidime, whilst Bergyella zoohelcum, was also resistant to $10 \mu \mathrm{g}$ of gentamicin. In comparison, all organisms were sensitive to Manuka honey and nine sensitive to Allicin.

Conclusions

This study highlights the prevalence of uncommon drug resistant microorganisms on the skin within a vulnerable population, highlighting the potential for $\mathrm{MH}$ or GE intervention.

\section{Background}

It is estimated that there were more than 27,000 amputations in the UK between 2015-2018, with around 176 leg, toe or foot amputations being carried out each week within the UK(1). The World Health Organisation estimates that the disabled community will continue to rise in proportion with the increase in life expectancy and associated ageing health difficulties(2). Therefore, there are many amputees that face common problems associated with the use of prostheses, such as malodour and continued infections(3)(4). Amputations are common with the prevalence of chronic wounds caused by vascular diseases such as diabetes mellitus (5) -whereby the wounds cannot heal due to inflammation imbalances and infection (6); making recurrent infections especially problematic and leading to a continued risk of further amputation (7); therefore, the prevention of infections is essential in this group of individuals.

Amputees encounter numerous challenges whilst undertaking physical and sporting activities. This can be due to the increase in heat and moisture that occurs during exercise as a result of ineffective heat transfer inside an enclosed and insulated prosthetic (8). This not only leads to malodour but creates a suitable environment for microbiological colonisation (3) (9). One way in which prosthetic users can combat the development of malodour caused by these microorganisms is the use of commercial deodorants or antiperspirant products (10). Such products traditionally employ antimicrobials, such as triclosan, within their constituents (11). The use of triclosan and other topical antimicrobials is linked to the development of contact dermatitis and can help develop antimicrobial resistant microorganisms(12). Indeed, it has also been shown that certain microorganisms, which are resistant to triclosan, may also have increased resistance to commonly used antibiotics(13). 
Certain natural products are effective as antimicrobial agents; particularly garlic (allicin) and Manuka honey (14).Topical applications of Medihoney ${ }^{\text {TM }}(\mathrm{MH})$ - a gamma irradiated Manuka honey occasionally embedded in dressings - has been used extensively in a range of healthcare products (15)(16); and for use on chronic wounds such as pressure ulcers and sores (17) .Garlic, specifically, one of its bioactive components allicin (diallyl thiosulfonate) has been used to promote wound healing (18) and has antimicrobial properties both in extracts and volatile components (19).

The microflora found on the skin is usually protective (20), and can commonly consist of Staphylcooccus spp; however, when translocated into a wound, infection can occur (21). Common aetiological agents in a wound infection can consist of endogenous organisms from that area (e.g., from the surface of the skin to the deeper layers of a wound) such as: Staphylococcus aureus (22), Streptococcus pyogenes (23) and Candida albicans (24).

Aetiological agents of wound infections can include both exogenous organisms from the environment and endogenous organisms that have been translocated from another area of the body. Such organisms can consist of; Enterococci from the gastrointestinal tract (25), Clostridium tetani, from the soil and other external environmental sources (26), and Bacillus cereus, common in nosocomial surgical infections (especially in the immunocompromised group)(27). In addition, many fungal infections stem from endogenous fungi, mainly affecting immunocompromised individuals (28).

Our objectives were two-fold. Firstly, to isolate and identify some of the potentially pathogenic microorganisms found on the surface of the skin at the skin/prosthesis interface of prosthetic limbs worn by disabled athletes. Secondly, once isolated, we determine the microorganisms' antimicrobial susceptibility, including their susceptibility to both Manuka honey and allicin.

\section{Materials}

\section{Control Microorganisms}

Control organisms were employed to check the accuracy of the general microbiological methods and consisted of $S$. aureus, Lactobacillus acidophilus, Pseudomonas aeruginosa, Escherichia coli, Streptococcus pyogenes, Streptococcus pneumoniae, C albicans and S. epidermidis. Strains were provided by Cardiff Metropolitan University culture collections.

\section{Antibiotics}

Antibiotic sensitivity discs included: penicillin (1.5 units), erythromycin (10 $\mu \mathrm{g})$, ampicillin $(10 \mu \mathrm{g})$, vancomycin $(30 \mu \mathrm{g})$, ceftazidime $(10 \mu \mathrm{g})$, ciprofloxacin $(10 \mu \mathrm{g})$, gentamicin $(10 \mu \mathrm{g})$ and colistin-sulphate $(50 \mu \mathrm{g})$ and were purchased from Merck, UK.

\section{General laboratory media}

All laboratory media and reagents were prepared as per manufacturer's instructions and were sterilised at $121^{\circ} \mathrm{C}$ for 15 minutes at 15 PSI.

All tests were performed in triplicate excluding the analytical profile index (API®) and $B B L^{\mathrm{Tm}}$ tests. In the case of $\mathrm{API}$ and $\mathrm{BBL}$ tests, isolates were equilibrated at room temperature $\left(21 \pm 1^{\circ} \mathrm{C}\right)$ before tests.

\section{Ethical approval}

of all procedures associated with participant swabbing was granted by Cardiff Metropolitan University on 20/06/2019 (reference: STA-1115) and for further bacterial identification as part of a postgraduate student project (reference: PGT-2244) on the 06/12/2019.

\section{Methods}

\section{Swab Collection}


Using a network of established contacts, eleven participants were recruited with either a single or double lower limb amputation. Participants were asked to swab the skin at the skin/prostheses interface, this was defined as the area of skin directly in contact with the socket and/or liner. A participant information sheet outlined the objectives of the study and detailed the correct method of swabbing and best practice to avoid contamination. Swabs contained a stabilising solution to ensure survival, but not proliferation of isolates and in all cases, swabs were analysed within 72 hours of being obtained. Upon receipt, swabs were assigned random participant number/letter combinations to ensure confidentiality.

\section{Isolate recovery}

Once received, each swab was vortex mixed for 30 seconds and immediately inoculated onto duplicate tryptone soya agar (TSA) and nutrient agar (NA). Swabs were also inoculated onto Sabouraud agar (SA) (Fisher scientific, UK) plates. Plates were inverted and incubated at $37^{\circ} \mathrm{C}$ for 18 hours. The morphology of the cultured swab samples and further isolates were assessed according to the Observational Assessment of Cultural Appearance (29) and further isolated into visually pure cultures. Single colonies were sub-cultured onto TSA/SA and incubated as previously described to ensure purity.

\section{Microbiological identification methods}

Following recovery onto solid media agar we employed the following general microbiological methods; Gram stain (30), Catalase test (31), Oxidase test (32), Lactose fermenting capability (33) (34), haemolytic capability (33) (35), Staphaurex (36) (37), mannitol fermenting capability (33) (38), Streptex (39) (40); API Staph (41) (42), 20E (43) (44) and Candida (45) (46) and BBL Crystal Identification systems (Gram-positive and Enteric and Non-fermenter) (47) (48).

\section{Bacterial standardisation}

A single colony of each isolate was inoculated into $20 \mathrm{~mL}$ of sterile tryptone soya broth (TSB) and incubated at $37^{\circ} \mathrm{C} 18 \mathrm{hrs}$. The bacterial suspension was then centrifuged at $5000 \mathrm{G}$ for 3 minutes. The resultant solution was standardised to an optical density of 0.05 at $660 \mathrm{~nm}$, this was calculated to be $5.8 \times 10^{6}-1.24 \times 10^{8} \mathrm{CFU} \cdot \mathrm{mL}^{-1}$ for each microorganism tested. This was completed prior to any antimicrobial testing.

\section{Preparation of Allicin (Garlic extract)}

Allicin (fisher scientific, UK) was prepared by diluting $5000 \mu \mathrm{g} \cdot \mathrm{ml}^{-1}(\mathrm{v} / \mathrm{v})$ Allicin in $9 \mathrm{ml}$ of sterile nutrient broth (NB) to create a $500 \mu \mathrm{g} \cdot \mathrm{ml}^{-1}$ (v/v) allicin stock solution. This was stored at $3 \mathrm{C}$ in the dark and used on the day of production.

\section{Preparation of Medihoney ${ }^{\mathrm{m}}$ Stock}

Medical grade Manuka honey (Medihoney ${ }^{\mathrm{TM}}$ ) was purchased from Comvita ${ }^{\circledR}, 2.5 \mathrm{~g}$ of honey was homogenised with $2.5 \mathrm{~mL}$ of sterile double concentrated NB using a desktop vortex for 2 minutes at room temperature. Following homogenisation, the stock solution was stored at $4^{\circ} \mathrm{C}$ in the dark and used on the day of production.

\section{Bacterial inhibition assays:}

\section{Determination of minimum inhibitory concentration with Allicin:}

Allicin was prepared as previously described and $190 \mu \mathrm{l}$ at concentrations of; $0,1.562,3.125,6.25,12.5,25,50,100,150,200$, 250 and $300 \mu \mathrm{g} \cdot \mathrm{ml}^{-1}$, respectively, before being added to each well within a 96 well plate. In all analyses a $0 \mathrm{mg} \mathrm{ml}^{-1} 190 \mu \mathrm{l}$ growth control (TSB), a media-only (TSB) (sterility check) triplicate well and a negative growth blank of GE (2nd sterility control) were employed. Analyses were completed in triplicate on three separate occasions.

\section{Determination of minimum inhibitory concentration with Manuka honey}

Manuka honey was prepared as previously described and $190 \mu \mathrm{l}$ at concentrations of; $0,3,6.25,9,12.5,15,25$ and $50 \% \mathrm{w} / \mathrm{v}$, before being added to each well within a 96 well plate. In all analyses a $0 \%(v / v) 190 \mu$ positive growth control (TSB), a mediaonly (sterility check) triplicate well and a negative growth blank of $\mathrm{MH}$ (2nd sterility control) were employed. Analyses were completed in triplicate on three separate occasions. 


\section{Bacterial inoculation}

Isolates were standardised as previously described, and $2 \mu \mathrm{l}$ of bacterial suspension was inoculated into the $190 \mu \mathrm{l}$ of the Manuka honey or Garlic suspension in a 96 well plate. The absorbance $(660 \mathrm{~nm})$ of each well was measured using a Biotek 800-TS multiplate reader at time 0 and following incubation at $37^{\circ} \mathrm{C}$ with shaking at $150 \mathrm{rpm}$ for $24 \mathrm{hr}$. The MIC was calculated by subtracting $T=0$ values from the $T=24$ hours values, a resultant value of less than 0.01 indicated no growth had occurred, Determination of Minimum Bactericidal Concentration

The bactericidal concentration was determined after 24 hours of incubation. From each test well, $50 \mu l$ of suspension was aseptically transferred to the surface of a sterile tryptone soya agar plate and spread evenly over the surface using a sterile spreader. Plates were left to dry within a laminar flow cabinet prior to inversion and incubated for 48 hours at $37^{\circ} \mathrm{C}$. No growth indicated a bactericidal concentration.

\section{Antibiotic Sensitivity Testing}

Antibiotic sensitivity testing was undertaken by firstly standardising each inoculum as previously described before inoculating $150 \mu$ of each isolate onto the surface of a NA plate and spreading evenly using a sterile spreader. The plates were inverted and incubated for 1 hour at $37^{\circ} \mathrm{C}$ for 1 hour to allow for bacterial adherence and settling; Following incubation, antibiotic discs were added to the surface of the agar as detailed in the Kirby-Bauer Disk Diffusion Susceptibility Test Protocol (49). Antibiotics employed included; penicillin (1.5 units), erythromycin $(10 \mu \mathrm{g})$, ampicillin $(10 \mu \mathrm{g})$, vancomycin $(30 \mu \mathrm{g})$ and were tested against isolates A, C, D, F, L, P and Q. Ceftazidime $(10 \mu \mathrm{g})$, ciprofloxacin $(10 \mu \mathrm{g})$, gentamicin $(10 \mu \mathrm{g})$ and colistin-sulphate $(50 \mu \mathrm{g})$ where tested against isolates $H, R, Y$ and $Z$. Plates were incubated for 24 hours in $37 \pm 1^{\circ} \mathrm{C}$ and resultant zones measured with a digital calliper $(\mathrm{mm})$. No zone of inhibition indicated resistance $(R)$ and zone of inhibition $>0 \mathrm{~mm}$ indicated sensitivity.

\section{Results}

\section{Participants}

Of the eleven participants that volunteered, nine swabs produced the individual isolates that were taken forward. Participants were all male and aged between 24-60 years of age. The average age of amputation was 23 years of age, whereby five participants reported bilateral amputation above both knees, two participants reported amputation below their right knee, one participant reported amputation below their left knee and a further participant reported a bilateral congenital defect through both knees. In addition, three participants had reported a previous infection in their amputated limb, yet only two had received treatment with debridement of tissue, antibiotics (flucloxacillin), and in two cases, further bone amputation.

\section{Bacterial Identification}

\section{Cultural Appearance}

Upon observation, the swab samples appeared to contain a range of different colonies, some of which were reoccurring throughout the participant swabs mainly white or yellow convex round mucoid colonies. Results from the Gram stain, catalase, oxidase, lactose fermenting capability, haemolytic capability, Sabouraud agar culture, Staphaurex ${ }^{\mathrm{TM}}$, Streptex ${ }^{\mathrm{T}}{ }^{\mathrm{M}}$, mannitol fermenting capability, $A P I \circledast$ Staph, $A P I \circledast 20 \mathrm{E}, A P I \circledast$ Candida and BBL ${ }^{\mathrm{T}}$ Crystal Identification tests are included in Figure 1.

Colonies that did not grow successfully or consistently in our selected growth media were removed from subsequent analysis.

MIC and MBC determination of Manuka Honey

The MIC and MBC of Manuka honey was tested against A: Bacillus cereus, C: Staphylococcus haemolyticus, D: Staphylococcus aureus, F: Micrococcus luteus, H: Pseudomonas oryzihabitans, L: Micrococcus spp., P: Bacillus subtilis, Q: Group D Streptococcus, R: Pantoea spp., Y: Enterobacter cloacae and Z: Bergyella zoohelcum. We observed that the mean MIC of Manuka honey against our isolates was $7.63(\mathrm{v} / \mathrm{v})$ and MBC was $13.90(\mathrm{v} / \mathrm{v})$, this is shown in Figure 2. 
We next investigated the effect of allicinagainst our isolates. As illustrated in Figure 3, we observed inhibition in eight isolates; Micrococcus luteus and Group D Streptococcus, were not inhibited the limit of our testing $300 \mu \mathrm{g} \cdot \mathrm{ml}^{-1}$.. In only one isolate, Bergyella zoohelcum, did we observe a bactericidal effect, at $200 \mu \mathrm{g} \mathrm{ml}^{-1}$.

Figure 3. The minimum inhibitory and bactericidal concentration of allicin against A: Bacillus cereus, C: Staphylococcus haemolyticus, D: Staphylococcus aureus, F: Micrococcus luteus, H: Pseudomonas orzyhabitans, L: Micrococcus spp., P: Bacillus subtilis, Q: Group D Streptococcus, R: Pantoea spp.,Y: Enterobacter cloacae and Z: Bergyella zoohelcum. we observed inhibition in eight isolates; in one isolate, B. zoohelcum, we observed a bactericidal effect, at $200 \mu \mathrm{gl}^{-1}$. Results are an average of three separate repeats.

Antibiotic Susceptibility

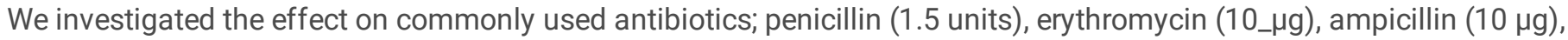
vancomycin $(30 \mu \mathrm{g})$, ceftazidime $(10 \mu \mathrm{g})$, ciprofloxacin $(10 \mu \mathrm{g})$, gentamicin $\left(10 \_\mu \mathrm{g}\right)$ and colistin-sulphate $\left(50 \_\mu \mathrm{g}\right)$. Results are shown in Table 1. We observed that Pantoea spp. and Enterobacter cloacae were sensitive to the tested antimicrobials; Pseudomonas oryzihabitans was resistant to a single antibiotic, whilst all other isolate were resistant to two of the employed antimicrobials.

Table 1

The antibiotic susceptibility profile of isolates against penicillin (1.5 units), erythromycin $(10 \mu \mathrm{g})$, ampicillin $(10 \mu \mathrm{g})$, vancomycin $(30 \mu \mathrm{g})$, ceftazidime $(10 \mu \mathrm{g})$, ciprofloxacin $(10 \mu \mathrm{g})$, gentamicin $(10 \mu \mathrm{g})$ and colistin-sulphate $(50 \mu \mathrm{g})$. Two isolates were sensitive to the employed antimicrobials, one was resistant to a single antibiotic, whilst the remaining 8 were observed to have resistance to two of the tested antibiotics. Key: $R=$ Resistance $(\mathrm{ZOI}=0 \mathrm{~mm}) ; \mathrm{S}=$ Sensitive $(\mathrm{ZOI}=>0 \mathrm{~mm}), \mathrm{NT}=$ Not Tested

\begin{tabular}{|c|c|c|c|c|c|c|c|c|c|c|c|}
\hline & \multicolumn{7}{|c|}{ Isolate ID } \\
\hline Susceptibility Profile & A & C & D & F & L & P & Q & H & R & Y & Z \\
\hline Penicillin (1.5 units) & R & R & R & R & R & R & R & NT & NT & NT & NT \\
\hline Erytromycin (10 ug) & S & S & S & S & S & S & S & NT & NT & NT & NT \\
\hline Ampicillin (10 ug) & R & R & R & R & R & R & R & NT & NT & NT & NT \\
\hline Vancomycin (30 ug) & S & S & S & S & S & S & S & NT & NT & NT & NT \\
\hline Ceftazidime (10 $\mu \mathrm{g})$ & NT & NT & NT & NT & NT & NT & NT & R & S & S & R \\
\hline Ciprofloxacin (10 $\mu \mathrm{gg})$ & NT & NT & NT & NT & NT & NT & NT & S & S & S & S \\
\hline Gentamicin (10 $\mu \mathrm{g})$ & NT & NT & NT & NT & NT & NT & NT & S & S & S & R \\
\hline Colistin-sulphate $(50 \mu \mathrm{g})$ & NT & NT & NT & NT & NT & NT & NT & S & S & S & S \\
\hline
\end{tabular}

\section{Discussion}

Eleven isolates were identified to species level: B. cereus, B. subtilis, E. cloacae, Micrococcus spp., M. luteus, Pantoea spp., P. oryzihabitans, S. haemolyticus, S. aureus, Group D Streptococcus and B. zoohelcum. To the best of our knowledge, $P$. oryzihabitans, and B. zoohelcum are not considered to be common colonisers of the skin (27)(50). Interestingly we did not recover any pathogenic fungi which may be due to a variety of factors such as a small sample size, medication or use of a 
medicated prosthetic material or a good equipment hygiene routine (51)(52).Although some of the isolated organisms could be considered endogenous bacteria, these results suggest that there are a variety of bacteria that are present on the skin and prosthetic devices of prosthesis users, including endogenous skin bacteria, endogenous gastrointestinal bacteria, and exogenous bacteria.

The isolated species have been shown to cause wound or skin and soft tissue infections; the exogenous and endogenous organisms were all opportunistic nosocomial pathogens that primarily affect immunocompromised patients (27)(53)(54)(55), or patients undergoing surgical procedures. such as an amputation (56)(57)(58)(59), excluding $B$. zoohelcum, which has been isolated from either a cat or dog bite and scratch wounds (60). Interestingly, this organism has also been observed in patients that have had long term contact with cats and dogs, and have been isolated from patients interacting with therapy dogs (61) (62).

Worryingly, we observed resistance to the tested antibiotics from all but two isolates. Eight of the eleven were resistant to two commonly used antibiotics whilst Pseudomonas oryzihabitans was resistant to just one, ceftazidime. Whilst we acknowledge that we employed a single concentration of each antibiotic, it was interesting to observe that for beta lactam antibiotics penicillin (1.5 units) and ampicillin $(10 \mu \mathrm{g})$, all tested strains were resistant. Two isolates, P. oryzihabitans and B. zoohelcum had observed resistance to the cephalosporin, ceftazidime $(10 \mu \mathrm{g})$, with $B$. zoohelcum also demonstrating resistance to the aminoglycoside, gentamicin $(10 \mu \mathrm{g})$.

None of the participants in the study reported an active known infection or had reported the use of any antimicrobials; however, three participants reported a previous infection which had required antibiotic intervention using floxacillin.

In comparison to the antibiotic treatment, all isolates were sensitive to $\mathrm{MH}$. $\mathrm{MH}$ had a bactericidal effect on all isolates with an MBC of $9 \% \mathrm{w} / \mathrm{v}$ against Micrococcus luteus and Pseudomonas oryzihabitans and $15 \% \mathrm{w} / \mathrm{v}$ against all other isolates. In comparison, whilst GE was able to inhibit the growth $(25-200 \mu \mathrm{g})$ of 8 isolates, in only one did we observe a bactericidal effect below $300 \mu \mathrm{g} / \mathrm{mL}$ B. zoohelcum.

To the best of our knowledge there has been no research exploring the use of honey and garlic as antimicrobials against Pantoea spp., P. oryzihabitans, S. haemolyticus and B. zoohelcum and this study highlights the potential for the use of either $\mathrm{MH}$ or GE against these microorganisms.

Based on the susceptibility results to the chosen antibiotics, there does not seem to be any explicit link between antibiotic resistance and a higher or lower MIC of MH or GE as concluded in a previous study (63), although this could be further explored using next generation sequencing. From this data, it is reasonable to suggested that GE and $\mathrm{MH}$ do not work by binding to the Penicillin Binding Proteins in the same way as $\beta$-lactams or bind to the aminoacyl-tRNA recognition site, like aminoglycosides.

This study represents one of the first to explore the microbial diversity of the skin-prosthesis interface and highlights the dangers posed by antimicrobial resistant microorganisms. Whilst the world is running out of antibiotics, the potential application of natural product inspired components, such as those derived from honey or plants should be explored in more detail. Results of this study also suggests there is a requirement for comprehensive bacterial identification and increased antimicrobial susceptibility testing on strains not routinely identified in wound infections; here we isolated the more common microorganisms such as Staphylococcus, alongside those less common such as Bergyella zoohelcum. Indeed, B. zoohelcum is commonly liked to cat and dog bites, with only 5 cases of infection reported worldwide (64), though this may be due to the fastidious growth requirements of the microorganism, leading to systematic underreporting.

Despite being multidrug resistant, the isolate in our study was observed to be the most sensitive in our collection against $\mathrm{MH}$ (3 $\% / 15 \% \mathrm{w} / \mathrm{v} \mathrm{MIC/MBC})$ and GE $(25 / 200 \mu \mathrm{g} / \mathrm{mL} \mathrm{MIC/MBC})$.

We conclude that antimicrobial resistant microorganisms pose a real threat to the general health and wellbeing of individuals who routinely use lower extremity prostheses. Results of this study identified a small cross section of microorganisms, which will form the basis of a much larger study. We would encourage the increased investigation into the use of natural product

Page $7 / 14$ 
extracts, such as Manuka honey and allicin as potential new and innovative interventions to help reduce the prevalence of multidrug resistant microorganisms that are present at the skin-prosthesis interface. In light of these findings, it would be pertinent to explore the use of alternative and novel approaches to ensure that hygiene of an individual's skin and their prosthetic liners and socket is maintained.

\section{Declarations}

Ethics Approval and consent to participate

Ethical approval of all procedures associated with participant swabbing was granted by Cardiff Metropolitan University on 20/06/2019 (reference: STA-1115) and for further bacterial identification as part of a postgraduate student project (reference: PGT-2244) on the 06/12/2019. Details available upon request.

The study was approved by the ethics committee of Cardiff Metropolitan University.

All methods were carried out in accordance with relevant guidelines and regulations. Informed consent was obtained from all participants as per our ethics application prior to the start of the study.

Consent for publication:

Not applicable.

Availability of data and materials

Data is available after reasonable request from the corresponding author; Dr James Blaxland

$\underline{\text { Competing Interests }}$

No conflicts of interest are declared by any authors

Funding

This project was funded by Cardiff Metropolitan University.

Author Contributions

Author Notes: RH, PS, JB, NR and RR were responsible for visualisation, investigation, methodology development, formal analysis and validation, RH, PS and JB for Writing.

Acknowledgements

We would like to acknowledge the Research and Innovation department at Cardiff Met for the competitive funding received for this project.

\section{References}

1. Diabetes UK. 26,378 diabetes-related lower limb amputations in the last three years [Internet]. Diabetes UK. 2018 [cited 2021 Aug 9]. Available from: https://www.diabetes.org.uk/about_us/news/lower-limb-amputations

2. World Health Organisation. Guidelines for Training Personnel in Developing countries for Prosthetics and Orthotics Services [Internet]. 2005 [cited 2020 Sep 7]. Available from: https://apps.who.int/iris/bitstream/handle/10665/43127/9241592672.pdf? sequence=1

3. Frölke JPM, van de Meent H. [The endo-exo prosthesis for patients with a problematic amputation stump]. Ned Tijdschr Geneeskd. 2010;154:A2010. 
4. Gholizadeh H, Abu Osman NA, Eshraghi A, Ali S, Yahyavi ES. Satisfaction and problems experienced with transfemoral suspension systems: a comparison between common suction socket and seal-in liner. Arch Phys Med Rehabil. 2013 Aug;94(8):1584-9.

5. Beyaz S, Güler ÜÖ, Bağır GŞ. Factors affecting lifespan following below-knee amputation in diabetic patients. Acta Orthop Traumatol Turc [Internet]. 2017 Oct [cited 2020 Jul 9];51(5):393-7. Available from: https://www.ncbi.nlm.nih.gov/pmc/articles/PMC6197166/

6. Lim JZM, Ng NSL, Thomas C. Prevention and treatment of diabetic foot ulcers. J R Soc Med [Internet]. 2017 Mar [cited 2020 Nov 1];110(3):104-9. Available from: https://www.ncbi.nlm.nih.gov/pmc/articles/PMC5349377/

7. Weledji EP, Fokam P. Treatment of the diabetic foot - to amputate or not? BMC Surg [Internet]. 2014 Oct 24 [cited 2020 Nov 1];14. Available from: https://www.ncbi.nlm.nih.gov/pmc/articles/PMC4218993/

8. Ghoseiri K, Zheng YP, Leung AKL, Rahgozar M, Aminian G, Lee TH, et al. Temperature measurement and control system for transtibial prostheses: Functional evaluation. Assistive Technology [Internet]. 2018 Jan 1 [cited 2020 Jun 25];30(1):16-23. Available from: https://doi.org/10.1080/10400435.2016.1225850

9. Cooper S. Bacterial Growth and Division: Biochemistry and Regulation of Prokaryotic and Eukaryotic Division Cycles. Elsevier; 2012. 528 p.

10. Responses to amputee odor question - OPEDGE.COM [Internet]. [cited 2020 Jun 25]. Available from: https://opedge.com/OANDPL/ViewMessage/6539CC54-6905-428D-9A4B-982C9E674B37

11. Campbell L, Zirwas MJ. Triclosan. Dermatitis. 2006 Dec;17(4):204-7.

12. Westfall C, Flores-Mireles AL, Robinson JI, Lynch AJL, Hultgren S, Henderson JP, et al. The Widely Used Antimicrobial Triclosan Induces High Levels of Antibiotic Tolerance In Vitro and Reduces Antibiotic Efficacy up to 100-Fold In Vivo. Antimicrobial Agents and Chemotherapy [Internet]. [cited 2021 Jul 27];63(5):e02312-18. Available from: https://journals.asm.org/doi/full/10.1128/AAC.02312-18

13. Carey DE, McNamara PJ. The impact of triclosan on the spread of antibiotic resistance in the environment. Front Microbiol [Internet]. 2015 Jan 15 [cited 2021 Aug 8];5:780. Available from: https://www.ncbi.nlm.nih.gov/pmc/articles/PMC4295542/

14. Pattamayutanon P, Angeli S, Thakeow P, Abraham J, Disayathanoowat T, Chantawannakul P. Biomedical Activity and Related Volatile Compounds of Thai Honeys from 3 Different Honeybee Species. Journal of Food Science [Internet]. 2015 [cited 2020 Jul 20];80(10):M2228-40. Available from: https://onlinelibrary.wiley.com/doi/abs/10.1111/1750-3841.12993

15. The Immense Benefits Of Medihoney | Comvita ${ }^{\circledR}$ Official Website - UK [Internet]. [cited 2020 Oct 26]. Available from: https://www.comvita.co.uk/blog-article/the-immense-benefits-of-medihoney/4700277

16. Robson V, Dodd S, Thomas S. Standardized antibacterial honey (Medihoney ${ }^{\mathrm{TM}}$ ) with standard therapy in wound care: randomized clinical trial. Journal of Advanced Nursing [Internet]. 2009 [cited 2020 Jul 18];65(3):565-75. Available from: https://onlinelibrary.wiley.com/doi/abs/10.1111/j.1365-2648.2008.04923.x

17. Biglari B, Linden PH, Simon A, Aytac S, Gerner HJ, Moghaddam A. Use of Medihoney as a non-surgical therapy for chronic pressure ulcers in patients with spinal cord injury. Spinal Cord. 2012 Feb;50(2):165-9.

18. Alhashim M, Lombardo J. Mechanism of Action of Topical Garlic on Wound Healing. Dermatol Surg. 2018 May;44(5):6304.

19. Reiter J, Levina N, van der Linden M, Gruhlke M, Martin C, Slusarenko AJ. Diallylthiosulfinate (Allicin), a Volatile Antimicrobial from Garlic (Allium sativum), Kills Human Lung Pathogenic Bacteria, Including MDR Strains, as a Vapor. Molecules. 2017 Oct 12;22(10).

20. Chiu L, Bazin T, Truchetet M-E, Schaeverbeke T, Delhaes L, Pradeu T. Protective Microbiota: From Localized to LongReaching Co-Immunity. Front Immunol [Internet]. 2017 Dec 7 [cited 2020 Nov 1];8. Available from: https://www.ncbi.nlm.nih.gov/pmc/articles/PMC5725472/

21. Cogen AL, Nizet V, Gallo RL. Skin microbiota: a source of disease or defence? Br J Dermatol [Internet]. 2008 Mar [cited 2020 Nov 1];158(3):442-55. Available from: https://www.ncbi.nlm.nih.gov/pmc/articles/PMC2746716/ 
22. Tong SYC, Davis JS, Eichenberger E, Holland TL, Fowler VG. Staphylococcus aureus Infections: Epidemiology, Pathophysiology, Clinical Manifestations, and Management. Clinical Microbiology Reviews [Internet]. 2015 Jul 1 [cited 2020 Jul 20];28(3):603-61. Available from: https://cmr.asm.org/content/28/3/603

23. Stevens DL, Bryant AE. Impetigo, Erysipelas and Cellulitis. In: Ferretti JJ, Stevens DL, Fischetti VA, editors. Streptococcus pyogenes: Basic Biology to Clinical Manifestations [Internet]. Oklahoma City (OK): University of Oklahoma Health Sciences Center; 2016 [cited 2020 Feb 13]. Available from: http://www.ncbi.nlm.nih.gov/books/NBK333408/

24. Kühbacher A, Burger-Kentischer A, Rupp S. Interaction of Candida Species with the Skin. Microorganisms [Internet]. 2017 Jun 7 [cited 2020 Jul 20];5(2). Available from: https://www.ncbi.nlm.nih.gov/pmc/articles/PMC5488103/

25. Rajkumari N, Mathur P, Misra MC. Soft Tissue and Wound Infections Due to Enterococcus spp. Among Hospitalized Trauma Patients in a Developing Country. J Glob Infect Dis [Internet]. 2014 [cited 2020 Jul 20];6(4):189-93. Available from: https://www.ncbi.nlm.nih.gov/pmc/articles/PMC4265836/

26. George EK, De Jesus O, Vivekanandan R. Clostridium Tetani. In: StatPearls [Internet]. Treasure Island (FL): StatPearls Publishing; 2020 [cited 2020 Jul 20]. Available from: http://www.ncbi.nlm.nih.gov/books/NBK482484/

27. Bottone EJ. Bacillus cereus, a Volatile Human Pathogen. Clinical Microbiology Reviews [Internet]. 2010 Apr 1 [cited 2020 Jul 20];23(2):382-98. Available from: https://cmr.asm.org/content/23/2/382

28. Mayer FL, Wilson D, Hube B. Candida albicans pathogenicity mechanisms. Virulence. 2013 Feb 15;4(2):119-28.

29. Public Health England. UK Standards for Microbiology Investigations: Introduction to the preliminary identification of medically important bacteria and fungi from culture [Internet]. Standards Unit, Public Health England; 2017 [cited 2019 May 30]. Available from:

https://assets.publishing.service.gov.uk/government/uploads/system/uploads/attachment_data/file/610705/ID_1i2.pdf

30. Public Health England. UK Standards for Microbiology Investigations: Staining procedures [Internet]. Public Health England; 2019. Available from:

https://assets.publishing.service.gov.uk/government/uploads/system/uploads/attachment_data/file/802769/TP_39i3.pdf

31. Public Health England. UK Standards for Microbiology Investigations: Catalase Test [Internet]. 2019. Available from: https://www.gov.uk/uk-standards-for-microbiology-investigations-smi-quality-and-consistency-in-clinical-laboratories

32. Public Health England. UK Standards for Microbiology Investigations: Oxidase test [Internet]. Public Health England; 2019. Available from:

https://assets.publishing.service.gov.uk/government/uploads/system/uploads/attachment_data/file/771781/TP_26i4.pdf

33. Public Health England. UK Standards for Microbiology Investigations: Inoculation of culture media for bacteriology [Internet]. Public Health England; 2017. Available from:

https://assets.publishing.service.gov.uk/government/uploads/system/uploads/attachment_data/file/583859/Q_5i2.pdf

34. Jung B, Hoilat GJ. MacConkey Medium. In: StatPearls [Internet]. Treasure Island (FL): StatPearls Publishing; 2020 [cited 2020 Oct 22]. Available from: http://www.ncbi.nlm.nih.gov/books/NBK557394/

35. Payment P, Coffin E, Paquette G. Blood agar to detect virulence factors in tap water heterotrophic bacteria. Appl Environ Microbiol [Internet]. 1994 Apr [cited 2021 Aug 13];60(4):1179-83. Available from:

https://www.ncbi.nlm.nih.gov/pmc/articles/PMC201456/

36. van Griethuysen A, Bes M, Etienne J, Zbinden R, Kluytmans J. International Multicenter Evaluation of Latex Agglutination Tests for Identification of Staphylococcus aureus. J Clin Microbiol [Internet]. 2001 Jan [cited 2021 Jul 28];39(1):86-9. Available from: https://www.ncbi.nlm.nih.gov/pmc/articles/PMC87684/

37. Remel. Staphaurex [Internet]. 2011. Available from: https://assets.thermofisher.com/TFSAssets/MBD/Instructions/X7819.pdf

38. Ayeni FA, Andersen C, Nørskov-Lauritsen N. Comparison of growth on mannitol salt agar, matrix-assisted laser desorption/ionization time-of-flight mass spectrometry, VITEK® 2 with partial sequencing of 16S rRNA gene for identification of coagulase-negative staphylococci. Microb Pathog. 2017 Apr;105:255-9.

39. Bixler-Forell E, Martin WJ, Moody MD. Clinical evaluation of the improved streptex method for grouping streptococci. Diagn Microbiol Infect Dis. 1984 Apr;2(2):113-8. 
40. Remel. Streptex Rapid [Internet]. Remel Europe; 2016. Available from: https://www.thermofisher.com/documentconnect/document-connect.html?url=https\%3A\%2F\%2Fassets.thermofisher.com\%2FTFS-

Assets\%2FMBD\%2FInstructions\%2FX7797.pdf\&title=U3RyZXB0ZXggUmFwaWQ=

41. bioMérieux. API Staph [Internet]. 2013. Available from: https://www.mediray.co.nz/media/15784/om_biomerieux_testkits_ot-20500_package_insert-20500.pdf

42. Kloos WE, Wolfshohl JF. Identification of Staphylococcus species with the API STAPH-IDENT system. J Clin Microbiol [Internet]. 1982 Sep [cited 2021 Aug 3];16(3):509-16. Available from:

https://www.ncbi.nlm.nih.gov/pmc/articles/PMC272399/

43. bioMérieux. API 20 E [Internet]. 2002. Available from: http://biomanufacturing.org/uploads/files/587872707301898351api20einstructions.pdf

44. Holmes B, Willcox WR, Lapage SP. Identification of Enterobacteriaceae by the API 20E system. J Clin Pathol [Internet]. 1978 Jan [cited 2021 Aug 3];31(1):22-30. Available from: https://www.ncbi.nlm.nih.gov/pmc/articles/PMC476713/

45. bioMérieux. API Candida [Internet]. 2011. Available from: https://www.mediray.co.nz/media/15780/om_biomerieux_testkits_ot-10500_package_insert_-10500.pdf

46. Campbell CK, Davey KG, Holmes AD, Szekely A, Warnock DW. Comparison of the API Candida System with the AUXACOLOR System for Identification of Common Yeast Pathogens. J Clin Microbiol [Internet]. 1999 Mar [cited 2021 Aug 3];37(3):8213. Available from: https://www.ncbi.nlm.nih.gov/pmc/articles/PMC84570/

47. BD. BBL CrystaI ${ }^{\mathrm{TM}}$ Identification Systems Gram-Positive ID Kit [Internet]. 2002. Available from: https://legacy.bd.com/ds/technicalCenter/clsi/clsi-Crysgp.pdf

48. BD. BBL Crystal ${ }^{\mathrm{TM}}$ Identification Systems Enteric/Nonfermenter ID Kit [Internet]. 2001. Available from: https://legacy.bd.com/ds/technicalCenter/clsi/clsi-CrysE_nf.pdf

49. Hudzicki J. Kirby-Bauer Disk Diffusion Susceptibility Test Protocol. American Society for Microbiology; 2009.

50. Dutkiewicz J, Mackiewicz B, Kinga Lemieszek M, Golec M, Milanowski J. Pantoea agglomerans: a mysterious bacterium of evil and good. Part III. Deleterious effects: infections of humans, animals and plants. Ann Agric Environ Med. 2016 Jun 2;23(2):197-205.

51. Geng L, Xu M, Yu L, Li J, Zhou Y, Wang Y, et al. Risk factors and the clinical and surgical features of fungal prosthetic joint infections: A retrospective analysis of eight cases. Exp Ther Med [Internet]. 2016 Aug [cited 2020 Nov 4];12(2):991-9. Available from: https://www.ncbi.nlm.nih.gov/pmc/articles/PMC4950886/

52. 26: Skin Problems of the Amputee | O\&P Virtual Library [Internet]. [cited 2020 Nov 4]. Available from: http://www.oandplibrary.org/alp/chap26-01.asp

53. Davin-Regli A, Pagès J-M. Enterobacter aerogenes and Enterobacter cloacae; versatile bacterial pathogens confronting antibiotic treatment. Front Microbiol [Internet]. 2015 May 18 [cited 2020 Jul 31];6. Available from: https://www.ncbi.nlm.nih.gov/pmc/articles/PMC4435039/

54. Okwundu N, Mercer J. Pantoea agglomerans cutaneous infection. Journal of Dermatology and Dermatologic Surgery [Internet]. 2019 Jan 1 [cited 2020 Jul 31];23(1):41-41. Available from: https://go.gale.com/ps/i.do? $p=H R C A \& s w=w \& i s s n=23522410 \& v=2.1 \& i t=r \& i d=G A L E \% 7 C A 571321277 \&$ sid=googleScholar\&linkaccess=abs

55. Tena D, Fernández C. Pseudomonas oryzihabitans: an unusual cause of skin and soft tissue infection. Infectious Diseases [Internet]. 2015 Nov 2 [cited 2020 Jul 31];47(11):820-4. Available from:

https://www.tandfonline.com/doi/abs/10.3109/23744235.2015.1034170

56. Barros EM, Ceotto H, Bastos MCF, dos Santos KRN, Giambiagi-deMarval M. Staphylococcus haemolyticus as an Important Hospital Pathogen and Carrier of Methicillin Resistance Genes. J Clin Microbiol [Internet]. 2012 Jan [cited 2020 Jul 20];50(1):166-8. Available from: https://www.ncbi.nlm.nih.gov/pmc/articles/PMC3256717/

57. Turnbull P. Medical Microbiology - NCBI Bookshelf [Internet]. 4th ed. 1996 [cited 2020 Jul 31]. Available from: https://www.ncbi.nlm.nih.gov/books/NBK7627/ 
58. Bowler PG, Duerden BI, Armstrong DG. Wound Microbiology and Associated Approaches to Wound Management. Clin Microbiol Rev [Internet]. 2001 Apr [cited 2020 Jul 31];14(2):244-69. Available from:

https://www.ncbi.nlm.nih.gov/pmc/articles/PMC88973/

59. Russell AD. 4 - Mechanisms of Bacterial Resistance to Antibiotics and Biocides. In: Ellis GP, Luscombe DK, Oxford AW, editors. Progress in Medicinal Chemistry [Internet]. Elsevier; 1998 [cited 2020 Jul 31]. p. 133-97. Available from: http://www.sciencedirect.com/science/article/pii/S0079646808700365

60. Lin W-R, Chen Y-S, Liu Y-C. Cellulitis and Bacteremia Caused by Bergeyella zoohelcum. Journal of the Formosan Medical Association [Internet]. 2007 [cited 2020 Jul 31];106(7):573-6. Available from:

https://linkinghub.elsevier.com/retrieve/pii/S0929664607600084

61. Muramatsu Y, Haraya N, Horie K, Uchida L, Kooriyama T, Suzuki A, et al. Bergeyella zoohelcum isolated from oral cavities of therapy dogs. Zoonoses Public Health. 2019 Dec;66(8):936-42.

62. Sharma S, Salazar H, Sharma S, Nasser MF, Dahdouh M. Bergeyella zoohelcum Bacteremia from Therapy Dog Kisses. Cureus. 2019 Apr 18;11(4):e4494.

63. Carter DA, Blair SE, Cokcetin NN, Bouzo D, Brooks P, Schothauer R, et al. Therapeutic Manuka Honey: No Longer So Alternative. Frontiers in Microbiology [Internet]. 2016 [cited 2020 Oct 14];7. Available from: https://www.ncbi.nlm.nih.gov/pmc/articles/PMC4837971/

64. Shukla SK, Paustian DL, Stockwell PJ, Morey RE, Jordan JG, Levett PN, et al. Isolation of a Fastidious Bergeyella Species Associated with Cellulitis after a Cat Bite and a Phylogenetic Comparison with Bergeyella zoohelcum Strains. Journal of Clinical Microbiology [Internet]. 2004 Jan 1 [cited 2021 Aug 12];42(1):290-3. Available from:

https://journals.asm.org/doi/full/10.1128/JCM.42.1.290-293.2004

\section{Figures}

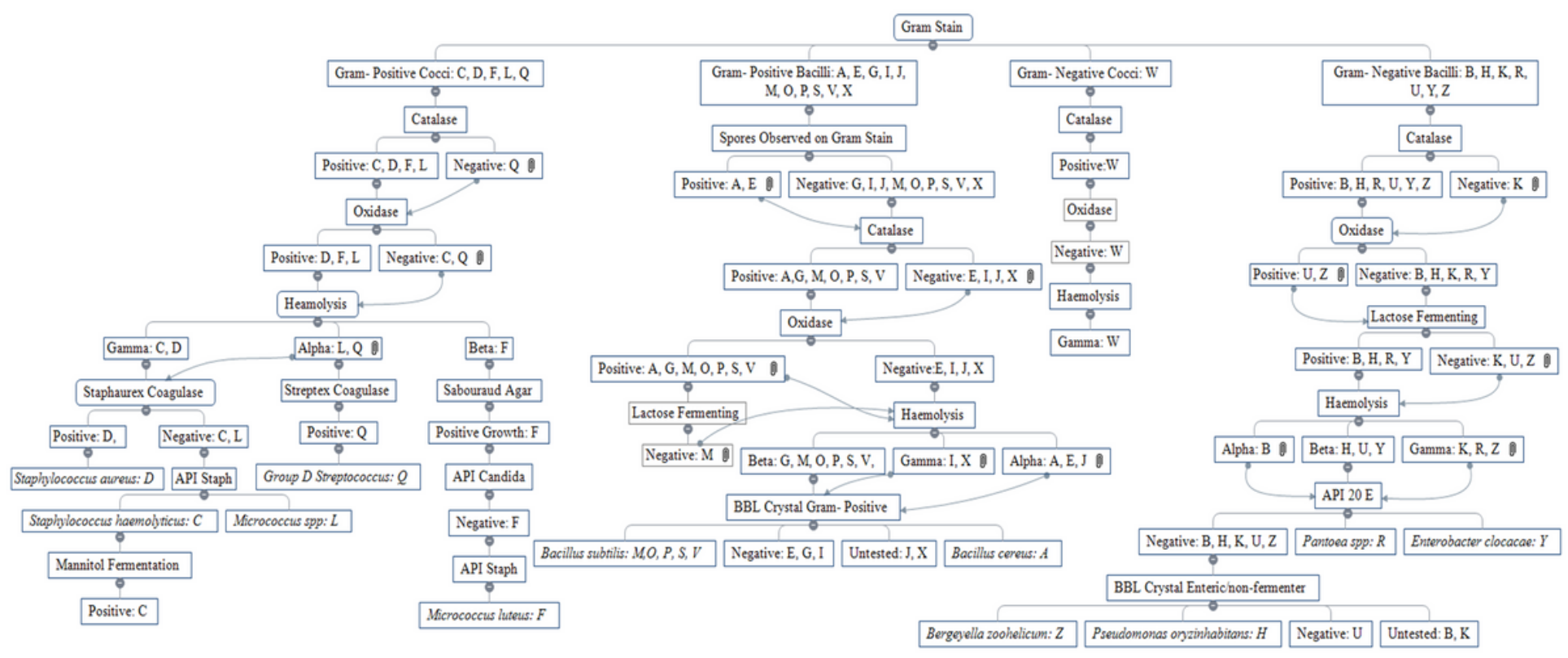

Figure 1

The identification process of nine isolates. Analysis began with Gram staining, Catalase test, Oxidase test, Lactose fermenting capability, haemolytic capability, Staphaurex latex agglutination test, mannitol fermenting capability, Streptex ${ }^{\mathrm{TM}}$ Latex Agglutination Test; with final identification related to API testing kits (Stap, 20E, Candida) and BBL crystal tests. Isolates identified and taken forward for further analysis included; A: Bacillus cereus, C: Staphylococcus haemolyticus, D: Staphylococcus aureus, F: Micrococcus luteus, H: Pseudomonas oryzihabitans, L: Micrococcus spp., P: Bacillus subtilis, Q: Group D Streptococcus, R: Pantoea spp.,Y: Enterobacter cloacae and Z: Bergyella zoohelcum. 


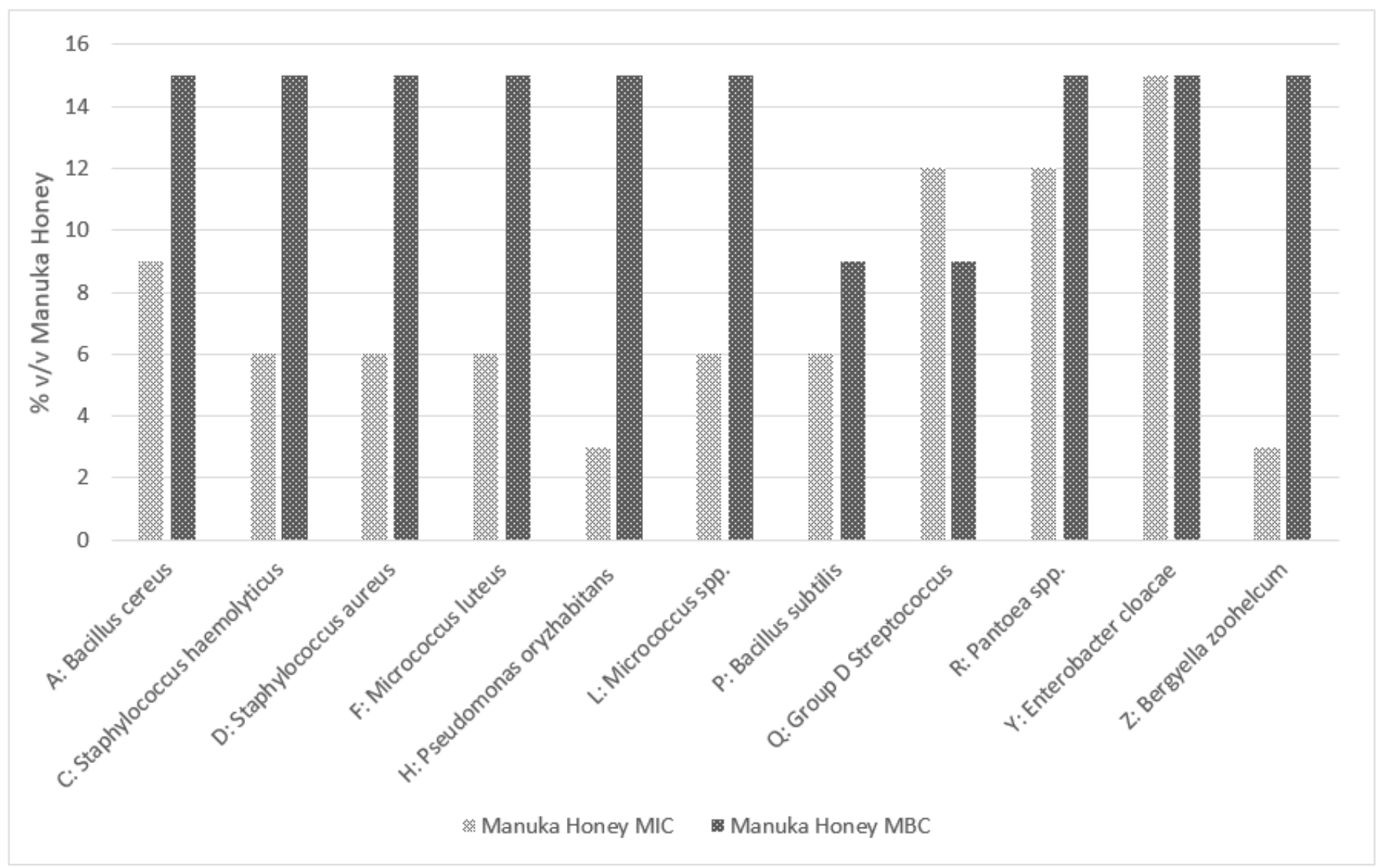

\section{Figure 2}

The minimum inhibitory and bactericidal concentration of Manuka honey against A: Bacillus cereus, C: Staphylococcus haemolyticus, D: Staphylococcus aureus, F: Micrococcus luteus, H: Pseudomonas oryzihabitans, L: Micrococcus spp., P: Bacillus subtilis, Q: Group D Streptococcus, R: Pantoea spp.,Y: Enterobacter cloacae and Z: Bergyella zoohelcum. Mean MIC $7.63(\mathrm{v} / \mathrm{v})$ and Mean MBC $13.90(\mathrm{v} / \mathrm{v})$. Results are an average of three separate repeats. 


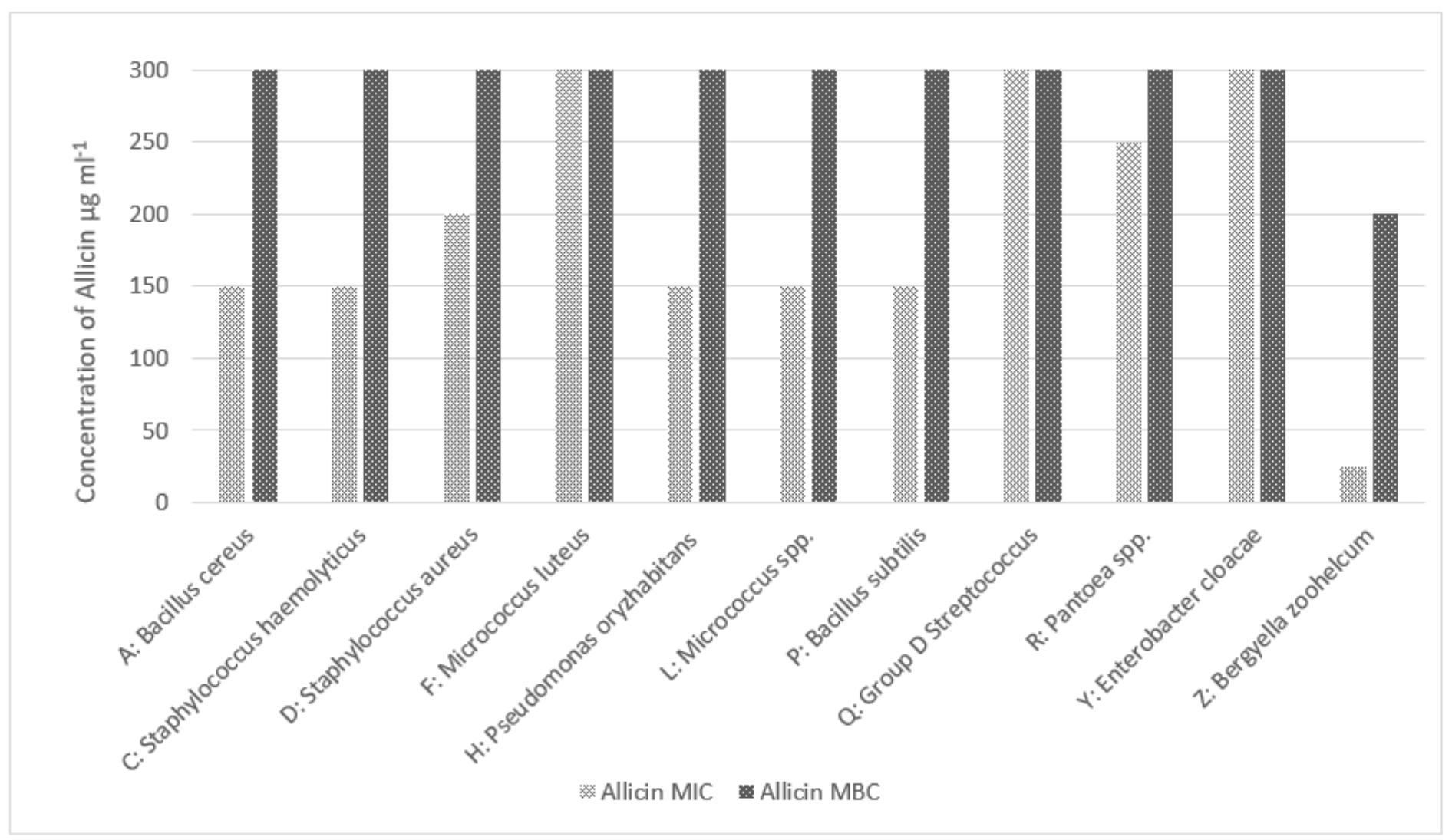

\section{Figure 3}

The minimum inhibitory and bactericidal concentration of allicin against A: Bacillus cereus, C: Staphylococcus haemolyticus, D: Staphylococcus aureus, F: Micrococcus luteus, H: Pseudomonas orzyhabitans, L: Micrococcus spp., P: Bacillus subtilis, Q: Group D Streptococcus, R: Pantoea spp.,Y: Enterobacter cloacae and Z: Bergyella zoohelcum. we observed inhibition in eight isolates; in one isolate, B. zoohelcum, we observed a bactericidal effect, at $200 \mu \mathrm{g} \mathrm{ml}-1$. Results are an average of three separate repeats. 